Global Conferences Series:

Social Sciences, Education and Humanities (GCSSSEH), Volume 3, 2019

The $1^{\text {st }}$ International Conference on Education, Social Sciences and Humanities

DOI: https://doi.org/10.326/hum0203

\title{
Improvement Of Long Service Based Technical Ability Through The Hula Hoop Media In Bulutangkis Game of 24 Makassar State High School Students
}

Muh. Adnan Hudain

Universitas Negeri Makassar, Indonesia

$\bowtie$ adnanhudain1@gmail.com

\begin{abstract}
The aims this research to improve students' ability to understand and curve the basic techniques of service in badminton games using Hula Hoop media. This research is a sports class action research. The research subjects were seventh grade students in SMP Negeri 24, Makassar. The results of the study concluded that: there was an increase in the ability to do long service using the Hula Hoop media on class VII students in SMP Negeri 24, Makassar. After going through the implementation of the teaching method with the Hula Hoop tool and at the end of the study showing that the ability to do long service in badminton games students showed improvement, it was shown from the results of the first cycle at the level of completion at standard 70, only 12 students or (34\%) declared complete and 23 students or $(66 \%)$ not yet completed. In the second cycle the level of completeness increased to 32 students or (91\%) and did not complete the decline to 3 students or $(9 \%)$. Thus it can be concluded that through teaching Hula Hoop's auxiliary media it can increase the long service ability students by $57 \%$.
\end{abstract}

Keyword: Learning Outcomes, basic techniques Long service, Hula Hoop. In Badminton games

\section{Introduction}

Physical education, sports, and health (penjasorkes) aims to develop aspects of health, physical fitness, critical thinking skills, emotional stability, social skills, reasoning and moral actions through physical activities and sports activities. Physical activity is the basis for humans to get to know the world and themselves which naturally develop in line with the times (Depdiknas,2003:1).

Physical education can in essence be seen as a combination of art and science education (artandscience). As an art, learning should demand the development of intuition, creativity, improvisation, and teacher expression (Samsudin, 2008: 16). As a science, physical education

Copyright (C) 2019, the Authors. Published by Redwhite Press.

Page | 96

This is an open access article under the CC BY-NC license

(http://creativecommons.org/licenses/by-nc/4.0). 
develops the fundamental abilities of the basic movement towards further physical abilities. Therefore, physical education at the junior high school level should be a momentum that will determine the continuation and development of physical education and also become a determining factor for future sports performance.

Physical education, sports and health is one of the subjects favored by students and plays an important role in the physical development and character of students. Therefore, it is necessary to develop interesting learning methods, especially those relating to student skills.

The facts in the field of teachers still provide material without striving to increase the activeness of students so that participation increases, especially using creative learning models that utilize existing facilities and infrastructure in schools. Especially in sevis learning in badminton games there are still many students who have not mastered good and correct long service techniques, usually children do only for fun without having the right long service skills, so in many long sevis games that fail and cannot resolved properly, so that mistakes often occur due to wrong service techniques or stuck on the net

In physical education today, the delivery of material must be adapted to the characteristics of the child. At school age children tend to play and compete, children will feel happy when in the learning process in the form of a game compared to the otrodok system of old models, with this change the teacher is required to have high creativity to achieve environmental situations and various forms of play comfortable and pleasant in accordance with the material to be delivered. To create a learning process like the one above, Penjas is very supportive, because of traditional educational educational materials such as marbles, gobak sodok, krlek and others. Badminton is also one of the sports of the game, but to play badminton a student is required to have basic skills and techniques including: service, returning the ball forhend, back hend, small ball neting, smash, and others. To study the material of badminton lessons requires the interest and courage of students to do it, so that new innovations are needed to create a pleasant situation in this badminton learning process and the use of appropriate learning methods and models. Especially in long service learning in badminton games there are still many students who have not mastered and the low scores obtained and do not reach the minimum completeness criteria (KKM).

Makassar 24 Public Middle School is one of the schools in Tamalate District, Makassar City. Based on the author's observation, the school has problems with limited facilities and infrastructure in penjas learning such as sports equipment.

In learning especially badminton, Makssar 24 Middle School has several balls and a field that is used for the badminton learning process. But in the process of learning badminton, many students do not master the basic techniques of badminton, especially in mastering basic service techniques in badminton games. Basic badminton techniques such as service, forehend, back hend, dropshot, smash, etc. are the basis of badminton games that need to be taught at school because many students do not master the basic techniques of playing good and right badminton. For this reason, the author wants to conduct a class VII action research on students of Makassar Public Middle School 24. 
Based on this background, the authors formulated the problem: "Does the learning method through" Hula Hoop "at 24 Makssar Middle School Tamalate District, Makassar City can improve long service capabilities?"

\section{Method}

This research is an action research because research is done to solve the problem of learning in the classroom. This research also includes descriptive research, because it describes how a method or model of learning is applied and how the results to be mitigated can be achieved. Action research can be understood from two sides, namely from the side of the teacher and the principal, from the side of the teacher commonly known as action class research. To conduct classroom action research, Oja and Sumarjan (in Titi Sugiarti 1997; 8), states that there are 4 types of classroom action research, namely (1) Research Teacher's Action as a researcher, (2) Collaborative action research, (3) simulative action research etherinteratif and (4) experimental social action research.

The target of this study was the process of learning physical education in students on long service learning material in badminton games for students of 24 Makssar Middle School.

Data Collection Instrument

Learning Device Development (PPP) is a learning tool that is used as a teacher's guide in teaching and arranged for each meeting. The teacher makes and prepares the PPP which contains fragments of syllabus, material, learning media, lesson plans, and assessment sheets.

Observation sheet of student activities to observe the extent of student activities during the learning process. This questionnaire is used to find out whether the students are enthusiastic about the learning method created by the writer. Observation is an instrument for conducting observations on the activities and creativity of students in learning, both in class and outside the classroom

\section{Results and Discussion}

Pre Cycle Results

From the results of preliminary research in long service learning there are still many students who have not mastered and the low value obtained and not reaching the KKM. From the number of students as many as 35 students only 12 students (34\%) were completed and as many as 23 students (66\%) were not completed from the determined KKM, namely 70.Hasil Penelitian

\section{Student Interest Response}

The research that has been carried out in 24 Makssar Public Middle School, Lembang Subdistrict, Pinrang Regency, in class VIII is a classroom action research. The classroom action research that has been conducted consists of two cycles, each of which consists of five stages, namely initial reflection, planning, action, observation, and reflection. The results of 
the research conducted on class VII students totaling 35 students through long service basic engineering learning through the game of hula hop on the response of students' interest in physical education learning, the results showed that interest in class VII students of Makssar 24 Middle School was included in the very good interest category of $61 \%$ can be seen in the response diagram of student interest

\section{First Cycle Discussion}

The first cycle was held on October 13, 2018 with a time allocation of $4 \times 35$ minutes. During the first cycle the teacher delivered material about the basic skills of long service movement skills carried out through hula hop games. After conducting the first cycle, the researcher conducted a discussion and reflection.

Results of Student Activity Observation

This first cycle, carried out when the physical education learning process takes place. Learning research is done by looking at the results of observations of student activities in pet soccer.

Tabel 1 : Observation results of student activities in the first cycle

\begin{tabular}{lcc}
\hline \multicolumn{1}{c}{ Research Aspect } & $\begin{array}{c}\text { Research } \\
\text { result }\end{array}$ & $\begin{array}{c}\text { Research } \\
\text { Indicator }\end{array}$ \\
\hline $\begin{array}{l}\text { Student activities in participating in learning } \\
\text { about the training of badminton balls through } \\
\text { hula hops }\end{array}$ & $62 \%$ & $70 \%$ \\
\hline
\end{tabular}

On the assessment of activities the learning outcomes for student activities reach $62 \%$. From the assessment of the learning outcomes, it has not been categorized as complete, because it has not reached the achievement indicator of $70 \%$, so the teacher or researcher must proceed to the second cycle to reach the target indicators of achieving student learning activities that have been determined by the teacher or researcher.

Description of Percentage of Student Skills

The purpose of the research was conducted including the implementation of this first cycle, which was to find out the improvement in the ability to pet badminton balls, which included a series of throwing and cuddling movements and carried out with a series of hula hop games. The way of evaluating is that researchers and teachers see and assess the basic motion analysis of students by using research instruments that have been made. The assessment of this learning is more directed at assessing their ability to move, so researchers only assess the results of movements that affect psychomotor and physical aspects. By way of assessing the results of his movements, learning can be categorized as complete and incomplete. To see the basic motion learning outcomes increase and not increase, the achievement of standardized learning is determined, namely $70 \%$ has been achieved or said to be complete. 
Based on the results of the calculation of the first cycle of achievement per basic motion in class VII students, amounting to 35 students reaching $57 \%$ for the throwing aspect it was said that it was not complete, for the pet aspect reaching $66 \%$ was classified as incomplete.

From the analysis of throwing aspects, it is said that it has not been completed, because the achievement of learning outcomes reaches $<70 \%$, from the calculation of the aspects of the pet it is said to be incomplete because $<70 \%$. The average percentage for psychomotor aspects in the first cycle reached $69 \%$ classified as incomplete. In the first cycle the average score of students for throwing aspect reached $65 \%$, consisting of 20 students (57\%) not complete, 15 students (43\%) completed. For the average pet aspect reaches $60 \%$, consisting of 23 students (66\%) not complete, 12 students (31\%) complete.

In this first cycle there are still many students who have not reached the KKM value, most of them are still afraid and have not mastered the basic techniques of soccer sila. Students who have not completed 23 students (66\%), who completed 12 students $(34 \%)$.

Description of Student's Affective and Cognitive Aspects

After assessing students' skills, then the researcher and teacher collaborator assess student activities in cognitive and affective aspects.

Based on the results of the calculation of the first cycle of achievement per aspect in class VIII students, amounting to 35 students reaching $9 \%$ for affective aspects, it was said not to be completed and 91\% completed. For cognitive aspects reaching $63 \%$ classified as incomplete, and 37\% complete.

From the analysis of affective aspects, the study was said to be complete because the achievement of learning outcomes reached $94 \%$, from the calculation of cognitive aspects it was said to be incomplete because it only reached $37 \%$. The total percentage for affective and cognitive aspects in the first cycle reached $31 \%$ classified as incomplete. In the first cycle the students' score for affective aspects reached $84 \%$, consisting of 3 students (9\%) were incomplete, 32 students (91\%) completed .. For the cognitive aspect category it reached $60 \%$, consisting of 22 students (65\%) incomplete and 13 students (37\%) completed.

Reflection Results in the First Cycle

The planning stage in the first cycle did not experience obstacles and went well, namely the Learning Implementation Plan (RPP), preparation of facilities and infrastructure as well as learning resources, assessment instruments in the form of basic motion checklist analysis and observation sheet learning activities for students who have been given good instructions.

While at the action stage, the teacher or researcher has difficulty in managing the class, in explaining and delivering the material to students is still not optimal so that in the implementation of the action there are still many students who do not know the motion assignments performed, besides that discipline in managing time is still not neatly arranged . In addition to the learning process, in terms of facilities and infrastructure there are still shortcomings, namely in the case of giving a turn to do the motion task it is still unclear.

The results of discussions conducted with colleagues, teachers or researchers are encouraged to provide creative ideas to get attention from students, so that students can be 
conditioned properly according to what is stated in the lesson plan. In addition, teachers or researchers must also be skilled in guiding students to be more active in participating in learning. While in establishing learning methods, there are facilities to add learning methods with interesting variations in the first cycle to be more effective in its implementation.

The method used in the second cycle must be more effective and interesting for students. Add variety of learning methods in the second cycle, which can use competitions between groups and change the rules of the game. Researchers are also advised to increase interaction with students and increase discipline in students, hopefully there are no students who play alone during the learning process takes place.

Second cycle discussion

The second cycle was held on October 29, 2018 with a time allocation of 4x35 minutes. In the implementation of the second cycle the teacher delivered material on the skills of the motion of badminton ball carried out through the game "Hula hop".

Results of Student Activity Observation

This second cycle, carried out when the physical education learning process takes place. Assessment of learning is done by looking at the results of observations of student activities in pet balls.

The research conducted in the second cycle also contained five stages, namely initial reflection, implementation, action, observation, and reflection. After carrying out and completing the second cycle, the researcher conducts discussions and reflections, then the learning results obtained from student activities as shown in the table.

Tabel 2 Results of Observation of Student Activities in the Second Cycle

\begin{tabular}{lcc}
\hline \multicolumn{1}{c}{ Research Aspect } & $\begin{array}{c}\text { Research } \\
\text { result }\end{array}$ & $\begin{array}{c}\text { Research } \\
\text { Indicator }\end{array}$ \\
\hline $\begin{array}{l}\text { Student activities in participating in learning } \\
\text { about the training of badminton balls through } \\
\text { hula hops }\end{array}$ & $86 \%$ & $70 \%$ \\
\hline
\end{tabular}

The assessment of student activities reaches $86 \%$. From the research the learning outcomes, can be categorized as complete, because it has reached the achievement indicator of $70 \%$.

The activities of students taking part in learning to pet badminton through hula hop games based on observations by researchers, the activities of students in following the learning of takraw ball through hula hop games also experienced an increase as in the table.

Tabel 3 Comparison of the results of the first cycle and the second cycle on observing student learning.

\begin{tabular}{ccc}
\hline No. & Research Cycle & Research result \\
\hline 1. & First & $62 \%$ \\
\hline 2 & Second & $86 \%$ \\
\hline
\end{tabular}


Table 4.3 above data shows that the first cycle of observations of students' activities in participating in training on badminton balls through hula hop games reached $62 \%$, while in the second cycle there was an increase of $24 \%$, which reached $86 \%$. Achievement of $86 \%$ has been said to be successful in an effort to improve the ability of students to take part in learning to pet badminton balls through hula hop games, and this means that following student learning has met cognitive, affective, psychomotor and physical aspects.

Results Description of Student Skills

The purpose of this research was to carry out this second cycle, to find out the improvement in the ability to pet badminton balls in the first cycle, which included a series of throwing and cuddling movements carried out through a series of games. research that has been made. Assessment of this learning is more directed at the assessment of his ability to move, so researchers and teacher collaborators only assess the results of movements that hit the psychomotor aspects. By way of assessing the results of their movements, learning can be categorized as complete and incomplete. To see basic motion learning outcomes increase and not increase, it is determined that the achievement of learning standardization is $70 \%$ already achieved or said to be complete.

Based on the results of the calculation of the second cycle of achievement per basic motion in class VIII students totaling 35 students reached $100 \%$ for the throwing aspect it was said to be complete, for the pet aspect reaching $91 \%$ classified as complete.

From the second assessment of the aspects analysis both are said to be complete because the achievement of learning outcomes is $>70 \%$. The average percentage for the psychomotor aspect of the second cycle reaches $100 \%$ complete. In the second cycle the student score for throwing aspect reaches $100 \%$, which is 35 students (100\% ) For the pet aspect it reached $91 \%$, consisting of 3 students (19\%) not complete, 32 students (91\%) completed.

Evaluation of the average psychomotor results in the first and second cycles can be known by assessment per aspect of motion. Improved learning on the activities of students in following the learning of takraw ball through hula hop is done by looking at the completeness of the movements carried out by 35 class VIII students. There are two aspects of assessment, namely throwing and pet aspects. From these two aspects the results in table 4.4 are obtained.

Tabel .4 Results of Completion of Psychomotor Aspects of Cycle I and Cycle II

\begin{tabular}{ccc}
\hline Cycle & Throwing & Pet \\
\hline First & 43 & 34 \\
\hline Second & 100 & 91 \\
\hline
\end{tabular}

From table 4.4 above, it can be seen that the first cycle of psychomotor aspects of students in learning to dance takraw through hula hop games reached $43 \%$, while in the second cycle there was an increase of $57 \%$ which reached $100 \%$ in the throwing aspect. Whereas in the coveted attendance in the first cycle it reached $34 \%$, while in the second cycle it increased 
$57 \%$, reaching $91 \%$. So in the second cycle there was an increase in throwing and pet learning. And the achievement of motion learning outcomes in learning to play badminton balls through hula hop games has very high criteria, categorized as successful or complete because the average grade value has reached the predetermined indicators of learning and has excellent qualifications (A).

By looking at the results of basic motion learning it can be seen in general that in physical education learning for basic technical services long service through hula hop games for student activities in general can be said to be achieved or succeeded in achieving $>70 \%$ have very high criteria and get excellent qualifications ( A)

Description of Student's Affective and Cognitive Aspects

After assessing the skills of students in the second cycle, then the researcher with the teacher collaborator assesses the activities of students in cognitive and affective aspects. Based on the results of the calculation of the second cycle of achievement per aspect in class VIII, 35 students reach $88 \%$ for affective aspects. complete, for cognitive aspects reaching $87 \%$ classified as complete.

From the two assessments the analysis of all aspects is said to be complete because the achievement of learning outcomes reaches $>70 \%$. The average percentage for affective and cognitive aspects in the second cycle reached $88 \%$, consisting of 2 students $(6 \%)$ not complete, 33 students (94\%) completed. For the affective aspects the class average reaches $88 \%$, consisting of 1 student (3\%) not complete, 34 students (97\%) complete. For the cognitive aspect category the class average reached $87 \%$, consisting of 2 students $(6 \%)$ incomplete, 235 students (94\%) completed.

The average assessment of the results of affective and cognitive aspects in the first cycle can be known by the assessment of aspects per aspect.

Increased learning on the activities of students in taking basic service learning in long service through hula hop is done by looking at the completeness of the movements carried out by 35 class VII students. There are two aspects of assessment, namely affective, cognitive. From these two aspects results are obtained, namely in table 4.5.

Tabel 4.5 The average grade results of affective and cognitive aspects of Cycle I and Cycle II

\begin{tabular}{cccc}
\hline No. & Cycle & Affective & Cognitive \\
\hline 1. & Pertama & $84 \%$ & $60 \%$ \\
\hline 2. & Kedua & $88 \%$ & $87 \%$ \\
\hline
\end{tabular}

From table 4.5 above, it can be seen that the first cycle of affective and cognitive aspects of students in basic badminton service learning basic techniques through hula hop media reached $60 \%$, while in the second cycle there was a $27 \%$ increase which reached $87 \%$.

So the affective and cognitive aspects of the second cycle experienced an increase in throwing and pet learning up to $27 \%$. And the achievement of motion learning outcomes in learning long service basic techniques on badminton through hula hop games has very high criteria, categorized as successful or complete because the average grade value has reached the set indicators in learning and has very high qualifications. 
By looking at the results of affective and cognitive aspects, it can be seen in general that in physical education learning for basic technical services long service through hula hop games for affective and cognitive aspects of students in general can be said to be achieved or successful that is $70 \%$ have very high criteria and get very good qualification.

Reflection Results in the Second Cycle

The planning phase in the second cycle in basic service learning is long service through hula hop games smoothly and in accordance with the learning scenario, while at the action stage, the teacher or researcher is able to overcome the problems that occur in the first cycle and the second cycle there is an increase in student activities in learning basic technique of long service through hula hop games.

In the second cycle, it can be concluded that the results of reflection in the second cycle are, the results of planning, action, observations made by the teacher or researcher have been going well and there have been changes. So that this cycle has been said to be successful and does not need to proceed to the next cycle.

Learning is as a process of changing behavior as a result of interactions between individuals and their environment (Husdarta and YudhaM.Saputra, 2000: 2) Learning as a change that lasts long in the lives of individuals and is not taken from birth or inheritance (Supandi, 1992: 4 ) Abdul Haling (2007: 1): Learning is a process that is carried out by someone to obtain a change in new behavior as a whole, as a result of his own experience in interaction with his environment.

Method or strategy is an effort to enhance success and success in achieving goals. According to Purwadarminta (1976), in general methods are ways that have been arranged and thought carefully to achieve a purpose. Whereas according to the Big Indonesian Dictionary, the method is a systemic way of working to facilitate the implementation of an activity in order to achieve the specified goals.

According to Hamzah B.Uno (2008: 17) Meode of learning is further classified into 3 (three) types, namely: 1) Organizational strategy (organizational strategy) 2) Delivery strategy (delivery strategy) 3) Management strategy (management strategy)

In the opinion of Grond land and Linn (1990) said that learning evaluation is a process of collecting, analyzing and interpreting systematically to determine the extent to which learning objectives are achieved. So that it can be concluded that evaluation is the process of describing, collecting, and presenting information that is useful for consideration and decision making. Learning evaluation is an evaluation in the field of learning.

\section{Conclusion}

Based on the results of data analysis and reflection in each cycle, the writer can draw conclusions and suggest the following:

The students 'activities in participating in basic long-service learning techniques on badminton games through the Hulahoop media reached $62 \%$, while in the second cycle after making changes to the learning scenario in the RPP, the students' activities in participating in learning reached $86 \%$. This means there is an increase of $24 \%$ in the second cycle. The results 
of these observations reached completeness in the first cycle of $31 \%$ with complete categories, while in the second cycle the success rate of motion learning reached $100 \%$ with complete categories. From the results of the data obtained through the student observation sheet after learning in the second cycle was completed, students were pleased with the existence of badminton service learning through this hula hoop media, students were also very enthusiastic in participating in learning and student learning outcomes in long service material especially in the aspect of swinging and accuracy is better than previous learning.

Increasing students' learning enthusiasm in any situation or condition, remember that learning is very fun while there is an opportunity and make students more accomplished, and develop your potential and skills in accordance with what is liked even though with limited means. Bring up creative ideas and innovations to improve the quality of teaching and learning and asking questions, does not mean we are ignorant or ignorant, resulting in practical, active, innovative, creative, effective and quality learning.

\section{Acknowledgments}

Deep gratitude is expressed to Head of Research Institute of Universits Negeri Makassar for the assistance in order for the research to be well conducted. Thanks to Head of SMP 24 Makassar for the permission given to the researchers to conduct the research in the faculty

\section{References}

Abdul Halim, (2007). Belajar dan Pembelajaran, UNM.Makassar

B. Uno, Hamzah. (2008). Teori Motivasi dan Pengukurannya, Jakarta: Bumi Aksara

BSMP, (2007). Standar isi untuk Satuan Pendidikan Dasar dan Menegah. Depdiknas. Jakarta.

Depdiknas. (2004). Model Pembelajaran Pendidikan Jasmani, Depdiknas. Jakarta.

Gronlund, Norman E. and Robert L. Linn (1990) Measurement and Evaluation in Teaching.

New York: Macmillan Publishing Company

Husdarta dan Yudha M. Saputra, (2000) Belajar dan Pembelajaran. Jakarta: Erlangga

Slamet (1988). Evaluasi Pendidikan. Bumi Aksara. Jakarta.

Sugiarti, Titik. (1997) Motivasi Belajar. Jakarta: Cerdas Pustaka

Suharjo, Untung, (1984). Pendidikan dan olahraga dan kesehatan. Bandung : Pioneer Jaya

Sugeng, Bandung. 2004. Sepak bola, Taktik dan teknik bermain. Jakarta : Raja Gafindo Persada

Suharno HP. (1993). Ilmu coaching umum.: Yayasan Sekolah Tinggi Olahraga Yogyakarta.

Supandi, (1992). Strategi Belajar Mengajar Penjaskes. Jakarta: Depdikbud Dirjen Dikti Proyek Pembinaan Tenaga Kependidikan

Wibawa. (2004). Bulutangkis. Raja Grfindo Pesadi. Jakarta 